\title{
Levels of available phosphorus and calcium for broilers from 8 to 35 days of age fed rations containing phytase ${ }^{1}$
}

\section{Adimar Cardoso Júnior ${ }^{2}$, Paulo Borges Rodrigues ${ }^{3}$, Antônio Gilberto Bertechini ${ }^{3}$, Rilke Tadeu Fonseca de Freitas ${ }^{3}$, Renato Ribeiro de Lima $^{4}$, Gustavo Freire Resende Lima ${ }^{5}$}

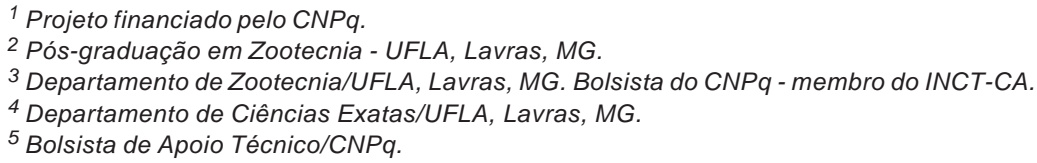

ABSTRACT - Two experiments using Cobb broiler chicks from 8 to 35 days of age were carried out to evaluate the effect of reducing levels of calcium and available phosphorus in diets supplemented with $500 \mathrm{ftu}$ phytase $/ \mathrm{kg}$ on the performance of the birds, the content of ashes in the tibia, the metabolizable energy of the diet, and the metabolizability of the dry matter and crude protein. It was used 1,404 broiler chicks in the experiment 1 to evaluate feed intake, weight gain, food conversion and percentage of the ashes in the tibia. In the experiment 2, simultaneously carried out with experiment 1, a total of 390 birds were transferred to a metabolism room to determine the metabolizable energy and metabolizability of the dry matter and crude protein. It was used in the two experiments, a complete random design in a $3 \times 4+1$ factorial scheme with three levels of available phosphorus $(0.375 ; 0.325$; and $0.275 \%)$ and four levels of calcium $(0.85 ; 0.75 ; 0.65$ and $0.55 \%)$ in the diets, supplemented with phytase. It was also used a control diet without phytase, based on corn and soybean bran, formulated with $0.425 \%$ of available phosphorus and $0.85 \%$ of calcium. In the experiment 1 , the reduction of levels of calcium and phosphorus did not cause a significant difference on the performance and percentage of bone ashes. The levels of calcium and available phosphorus used in the experiment 2 can be reduced down to 0.65 and $0.325 \%$, respectively, because the effects are similar to those obtained with the currently suggested levels.

Key Words: enzyme, minerals, nutritional requirement

\section{Níveis de fósforo disponível e de cálcio para frangos de corte de 8 a 35 dias de idade alimentados com rações contendo fitase}

\begin{abstract}
RESUMO - Dois experimentos com pintos de corte da linhagem Cobb no período de 8 a 35 dias de idade foram realizados para avaliar o efeito da redução dos níveis de cálcio e fósforo disponível (Pdisp) em rações suplementadas com 500 ftu de fitase/kg sobre o desempenho das aves, o teor de cinzas na tíbia, a energia metabolizável (EMAn) da dieta e a metabolizabilidade da matéria seca (MS) e da proteína bruta (PB). No experimento 1, foram utilizados 1.404 pintos de corte para avaliação do consumo de ração, do ganho de peso, da conversão alimentar e da porcentagem de cinzas na tíbia. No experimento 2, conduzido simultaneamente ao primeiro, um total de 390 aves foram transferidas para uma sala de metabolismo para determinação da EMAn e da metabolizabilidade da MS e PB. Nos dois experimentos, utilizou-se delineamento inteiramente casualizado, em esquema fatorial $3 \times 4+1$, com três níveis de fósforo disponível $(0,375 ; 0,325$ e $0,275 \%)$ e quatro níveis de cálcio $(0,85 ; 0,75$; 0,65 e $0,55 \%$ ) nas dietas, suplementadas com fitase. Também foi usada uma dieta controle sem fitase, à base de milho e farelo de soja, formulada com $0,425 \%$ de fósforo disponível e $0,85 \%$ de cálcio. No experimento 1 , a redução dos níveis de cálcio e fósforo não ocasionou diferença significativa no desempenho e na porcentagem de cinzas ósseas. Os níveis de cálcio e fósforo disponível utilizados no experimento 2 podem ser reduzidos em até 0,65 e $0,325 \%$, respectivamente, pois os efeitos são semelhantes aos obtidos com os níveis atualmente recomendados.
\end{abstract}

Palavras-chave: enzima, exigência nutricional, minerais

\section{Introduction}

Poultry feed are mainly constituted of vegetable origin food, which presents part of the phosphorus level in the form of an organic complex phytate, an anti nutritional factor that significantly decreases phosphorus availability in the food (Maga, 1982). Therefore, approximately 33\% of the total phosphorus present in the food is consumed by

Received September 9, 2008 and accepted October 1, 2009.

Corresponding author: adimarcjr@gmail.com; pborges@dzo.ufla.br 
the broilers. However, Segueilha et al. (1992) has shown the efficiency of exogenous addition of phytase enzyme in the feed to release the phosphorus present in the ingredients of vegetable origin in the phytate form. Moreover, it makes other minerals available, such as calcium, and also amino acids and energy, presenting themselves as an alternative to increase the nutritional value of much vegetal food.

Phytase does not only reduce the inorganic phosphorus supplementation, but also the minerals that can be released for absorption (Sebastian et al., 1996). Leske \& Coon (1999) show that phytase releases the bioavailability of phosphorus from vegetables and it increases the weight gain of the broilers. The phytase effect over the phosphorus availability was sufficiently studied and relatively well established (Borges et al., 1997), which do not occur to other complex minerals such as phytate and especially calcium.

Although many researches on calcium had been conduced, their main focus was to determine the nutritional requirements of this element by considering the lineage, the sex, feed consumption and its relation to other minerals of the feed, phosphorus in particular (Schoulten et al., 2002).

In aviculture, great performance is fundamental, associated with an adequate bone mineralization, as muscular development depends on a good bone support and it is essential to a good behavior of the musculoskeletal system. Broilers with bone development deficiency may suffer fractures during the gathering, transportation and slaughter, causing great losses because of the carcass rejection in the slaughterhouse.

Therefore, two experiments were carried out aiming to study the effects of levels of available phosphate and calcium in the feed with phytase for broilers from 8 to 35 days of age and to evaluate the performance and bone ash rate in the tibia of the broilers, the energetic values of the feed and metabolizability of the dry matter and the crude protein in the experimental feed.

\section{Material and Methods}

Commercial lineage Cobb 500 male chicks at one day of age, vaccinated against Marek disease and avipoxvirus, were raised in a conventional shed until 7 days of age. During this period, they received a broiler pre-initial feed, containing as basic ingredients corn and soybean meal (Table 1) formulated according to the recommendation by Rostagno et al. (2005).

The assays were carried out in a complete randomized design, in a $3 \times 4+1$ factorial scheme composed by three available phosphorus levels $(0.375 ; 0.325$ and $0.275 \%)$, four calcium levels ( $0.85 ; 0.75 ; 0.65$ and $0.55 \%$ ) and a phytase supplementation level (Ronozyme P5000 ${ }^{\circledR}$ ) of $500 \mathrm{PU} / \mathrm{kg}$ of feed. It was also used a control feed with $0.425 \%$ of available phosphorus, $0.85 \%$ of calcium, and no phytase.

The feeds were isonutritive (Table 2 ) and it was mainly composed of corn and soybean meal, using an inert material (kaolinite) for adjustments in the formula. The enzyme was added in the feed accordingly to recommendation by the manufacturer $(0.100 \mathrm{~kg} /$ ton of feed) aiming to supplement $500 \mathrm{PU} / \mathrm{kg}$ of feed.

Analyses of global variance were carried out for all diets to obtain the average square of residues in order to test the factorial and the Dunnett test at 5\%, comparing to the control diet in each one of the diets of the factorials.

There was a significant interaction between the calcium level and available phosphorus level according to the suitable development and regression studies performed to determine, within the studied interval, the adequate calcium levels and to compare the available phosphorus measures by using the Student - Newman - Keuls test (SNK), because only three available phosphorus levels were used in the feed.

It was used 1,404 broilers at 8 days of age and at an average initial weight of $141.8 \pm 12.8 \mathrm{~g}$, distributed in the boxes of a experimental shed for broilers, east-west orientated, prepared with a wood shaving litter, and electric

Table 1 - Nutritional composition of experimental feeds ${ }^{1,2}$

\begin{tabular}{|c|c|c|c|c|c|c|c|}
\hline Ingredient & $\begin{array}{c}\text { Metabolizable } \\
\text { energy }^{2}(\mathrm{kcal} / \mathrm{kg})\end{array}$ & $\begin{array}{c}\text { Dry } \\
\text { matter (\%) }\end{array}$ & $\begin{array}{l}\text { Crude } \\
\text { protein (\%) }\end{array}$ & $\begin{array}{l}\text { Calcium } \\
\text { (\%) }\end{array}$ & $\begin{array}{c}\text { Available } \\
\text { phosphorus (\%) }\end{array}$ & $\begin{array}{l}\text { Digestible } \\
\text { lysine }^{2}(\%)\end{array}$ & $\begin{array}{c}\text { Digestible } \\
\text { met }+\operatorname{cis}^{2}(\%)\end{array}$ \\
\hline Corn & 3381 & $89.51^{1}$ & $8.39^{1}$ & $0.03^{2}$ & $0.08^{2}$ & 0.21 & 0.33 \\
\hline Soybean meal & 2256 & $89.75^{1}$ & $46.1^{1}$ & $0.24^{2}$ & $0.18^{2}$ & 2.55 & 1.11 \\
\hline L-lysine $\mathrm{HCl}^{2}$ & 3762 & 98.5 & 85.8 & - & - & 78.8 & - \\
\hline DL-methionine $99 \%{ }^{2}$ & 4858 & 99.8 & 59.4 & - & - & - & 98.2 \\
\hline Soybean oil ${ }^{2}$ & 8790 & 99.6 & - & - & - & - & - \\
\hline Limestone $^{1}$ & - & - & - & 38.57 & - & - & - \\
\hline Dicalcicium phosphate ${ }^{1}$ & - & - & - & 22.06 & 18.32 & - & - \\
\hline
\end{tabular}

${ }^{1}$ Values obtained in the Animal Nutrition Laboratory of the DZO/UFLA.

${ }^{2}$ Values described by Rostagno et al. (2005). 
Table 2 - Composition of the experimental feeds

\begin{tabular}{|c|c|c|c|c|c|}
\hline \multirow[t]{4}{*}{ Composition in ingredients (kg) } & \multirow[t]{4}{*}{ Control } & \multicolumn{4}{|c|}{ Calcium level (\%) } \\
\hline & & 0.85 & 0.75 & 0.65 & 0.55 \\
\hline & & \multicolumn{4}{|c|}{ Available phosphorus level (\%) } \\
\hline & & $0.375 / 0.325 / 0.275$ & $0.375 / 0.325 / 0.275$ & $0.375 / 0.325 / 0.275$ & $0.375 / 0.325 / 0.275$ \\
\hline Corn & 61.000 & 61.000 & 61.000 & 61.000 & 61.000 \\
\hline Soybean meal & 32.000 & 32.000 & 32.000 & 32.000 & 32.000 \\
\hline Soybean oil & 2.800 & 2.800 & 2.800 & 2.800 & 2.800 \\
\hline Salt & 0.410 & 0.410 & 0.410 & 0.410 & 0.410 \\
\hline L-lysine $\mathrm{HCl}$ 99\% & 0.260 & 0.260 & 0.260 & 0.260 & 0.260 \\
\hline DL-methionine 99\% & 0.260 & 0.260 & 0.260 & 0.260 & 0.260 \\
\hline Mineral premix ${ }^{1}$ & 0.050 & 0.050 & 0.050 & 0.050 & 0.050 \\
\hline Vitamin premix ${ }^{2}$ & 0.050 & 0.050 & 0.050 & 0.050 & 0.050 \\
\hline Salinomycin $20 \%$ & 0.025 & 0.025 & 0.025 & 0.025 & 0.025 \\
\hline Zinc bacitracin & 0.005 & 0.005 & 0.005 & 0.005 & 0.005 \\
\hline Phytase $^{3}$ & 0.000 & 0.010 & 0.010 & 0.010 & 0.010 \\
\hline Limestone & 0.830 & $0.93 / 1.10 / 1.26$ & $0.68 / 0.84 / 1.01$ & $0.43 / 0.59 / 0.76$ & $0.175 / 0.34 / 0.50$ \\
\hline Dicalcium phosphate & 1.710 & $1.44 / 1.17 / 0.90$ & $1.44 / 1.17 / 0.90$ & $1.44 / 1.17 / 0.90$ & $1.44 / 1.17 / 0.90$ \\
\hline Inert & 0.600 & $0.76 / 0.86 / 0.97$ & $1.01 / 1.12 / 1.22$ & $1.26 / 1.37 / 1.47$ & $1.515 / 1.62 / 1.73$ \\
\hline \multicolumn{6}{|l|}{ Nutritional composition (calculated) } \\
\hline Metabolizable energy (kcal/kg) & 3053 & 3053 & 3053 & 3053 & 3053 \\
\hline Crude protein (\%) & 20.25 & 20.25 & 20.25 & 20.25 & 20.25 \\
\hline Available phosphorus (\%) & 0.425 & $0.375 / 0.325 / 0.275$ & $0.375 / 0.325 / 0.275$ & $0.375 / 0.325 / 0.275$ & $0.375 / 0.325 / 0.275$ \\
\hline Calcium (\%) & 0.85 & $0.52 / 0.854 / 0.853$ & $0.753 / 0.751 / 0.753$ & $0.653 / 0.651 / 0.654$ & $0.552 / 0.552 / 0.550$ \\
\hline Sodium (\%) & 0.20 & 0.20 & 0.20 & 0.20 & 0.20 \\
\hline Digestible lysine (\%) & 1.15 & 1.15 & 1.15 & 1.15 & 1.15 \\
\hline Digestible Met + Cis (\%) & 0.81 & 0.81 & 0.81 & 0.81 & 0.81 \\
\hline
\end{tabular}

${ }^{1}$ Content/kg of feed: vit. A - 13.000 UI; vit. D3 - 2.200 UI; vit. E - 30 mg; vit. K3 - 2.50 mg; vit. B1 - 2.20 mg; vit. B2 - 6 mg; vit. B6 - 3.30 mg; vit. B12 - 16 mg; biotin - $110 \mathrm{mg}$; nicotinic acid - $53 \mathrm{mg}$; penthothenic acid - $13 \mathrm{mg}$; folic acid - $1 \mathrm{mg}$; antioxidant - $120 \mathrm{mg}$.

2 Content/kg of feed: Mn 75 mg; Zn - 50 mg; Fe - 20 mg; Cu - 4 mg; I - 1.50 mg; Co - 0.20 mg; Se - 0.30 mg.

${ }^{3}$ Ronozyme $\mathrm{P} 5000^{\circledR}$

heater with an 100-Watts incandescent lamp, and a pendulous drinker and feeder. The broilers received the experimental diets in the period of 8 to 35 days of age and natural and/or artificial light for 24 hours. The broilers were randomly distributed in the boxes and experimental diets, with four replicates, each one with 27 birds. The birds had free access to water and experimental diets. The drinkers were washed daily and the feeder filled as needed.

At the end of the experimental period, the broilers and the feed were weighed to evaluate weight gain, feed intake and food conversion. At 35 days of age, two broilers with average weight from each repetition were slaughtered by cervical dislocation to remove the left tibia for analyses of the mineral matter (ash) in the bones.

Simultaneously to the performance experiment, 390 broilers with the same average weight of experiment 1 were transferred to a metabolism room with partial control of the temperature and artificial light for 24 hours. The broilers were randomly distributed in the battery cages, which contained trays under the floor, covered in plastic to facilitate the collect of excrete and to avoid losses. The broilers received the experimental feed during a preexperimental period (from 8 to 31 days of age), while the total excrete collects were performed during 32 and 34 days of age of the broilers, with two withdraws a day (at 9 a.m. and 4 p.m.) to avoid possible losses by fermentation, accordingly to Rodrigues et al. (2005). For the diets, it was established six repetitions of five birds, totalizing 30 broilers per experimental diet.

The maximum and minimum temperatures during the experimental period were 27 and $16^{\circ} \mathrm{C}$ for experiment 1 and 25 and $20^{\circ} \mathrm{C}$ for experiment 2 , respectively.

Water and feed were provided ad libitum during the experimental period, with the feeder being filled twice a day to avoid waste. The feed intake in each of the six experimental units per diet, composed of five birds, during the collect period, was recorded. The collected excretes were placed into plastic bags properly identified and stored in a freezer until the end of the collect period. Afterwards, the samples were weighted, homogenized, and 400 g-aliquots were collected for analyses. After the pre-drying in a hothouse ventilated at $65^{\circ} \mathrm{C}$, for a minimum period of 72 hours, analyses were performed on the dry matter (DM), nitrogen and gross energy (GE), according to the AOAC methodology (1990). Based on the obtained laboratorial results, the coefficients of the dry matter and crude protein were calculated, accordingly to the formulas presented bellow and the energetic values of the feed 
(apparent metabolizable energy corrected by the nitrogen balance - AMEn) by the formulas described by Matterson et al. (1965). The results were analyzed by using Statistics and Genetics Analyses System (SGAS) version 5.0 (UFV, 1992).

$$
\begin{aligned}
& \text { MCDM }=\frac{\text { ingested } \mathrm{DM} \text { - excreted } \mathrm{DM} \times 100}{\text { ingested } \mathrm{DM}} \\
& \mathrm{MCCP}=\frac{\text { ingested } \mathrm{CP}-\text { excreted } \mathrm{CP} \times 100}{\text { ingested CP }}
\end{aligned}
$$

where MCMD = metabolizability coefficient of dry matter; $\mathrm{DM}=$ dry matter; $\mathrm{MCMD}=$ metabolizability coefficient of crude protein; $\mathrm{CP}=$ crude protein.

\section{Results and Discussion}

When compared to the control diet, the broilers fed $0.325 \%$ of available phosphorus and $0.85 ; 0.75$; and $0.65 \%$ of calcium showed a higher consumption $(\mathrm{P}<0.05)$, than the ones that received $0.65 \%$ of calcium with $0.275 \%$ of available phosphorus. Also, the broilers that received $0.65 \%$ and $0.55 \%$ of calcium with $0.375 \%$ of available phosphorus presented higher feed consumption $(\mathrm{P}<0.05)$ when compared to the control diet. The higher absolute consumption value of feed was presented by the broilers that consumed the feed with the relationship calcium: AvP of $2: 1,0.65 \%$ and $0.325 \%$ of calcium and available phosphorus, respectively.

The results obtained in this work, related to feed consumption, are in agreement to those obtained by Qian et al. (1997), who state that, the more extensive relationship calcium: AvP, the lower feed consumption is. The diets with $0.65 \%$ and $0.325 \%$ of calcium and available phosphorus, respectively, promoted an increase of $6.01 \%$ in the feed consumption when compared to the control diet, like the other diets that promoted a higher feed consumption when compared to the control diet presented calcium:AvP ratio similar or superior than 2:1.

Although there was a difference in the feed intake between reported calcium levels and available phosphorus levels, the weight gain was superior $(\mathrm{P}<0.05)$ only in the broilers that received feed with 0.65 and $0.325 \%$ or 0.55 and $0.275 \%$ of calcium and available phosphorus, respectively, which corresponds to a $4.23 \%$ and $3.39 \%$ of increase, respectively, when compared to the control diet. However, the food conversion did not present significant difference $(\mathrm{P}>0.05)$ when compared to the one obtained with the normal level feed (no phytase supplementation).

There was no interaction $(\mathrm{P}>0.05)$ between the calcium and available phosphorus levels used in the experimental feed for the studied variables. The studied mineral levels might be reduced when phytase is used in the feed, consequently, it is possible to reduce the ingredients that will be used to provide these minerals, the calcitic limestone and bicalcic phosphate.

Reduction of calcium and available phosphorus levels by using phytase $(\mathrm{P}>0.05)$ in the feed did not alter the average values of the broilers in the studied period (Table 3 ), evaluated by the feed consumption, weight gain and food conversion, regardless to the studied calcium and available phosphorus levels.

The results obtained in the work partly agree to the ones obtained by Lan et al. (2002), and they completely agree to the ones obtained by Silva et al. (2006). The former found higher values to feed supplemented with phytase than those with no addition of the enzyme; the later found that intake and weight gain in feed with $0.35 \%$ of available phosphorus and $500 \mathrm{PU}$ of phytase $/ \mathrm{kg}$ feed were similar to the one with no phytase and $45 \%$ of available ones. These results are also in consonance with Santos et al. (2004) and Namkung \& Leeson (1999) who reported that the reduction of calcium and levels of available phosphorus in the diets supplemented with phytase did not harm the performance of the broilers.

According to Viveros et al. (2002), the development of the broilers that received feed supplemented with phytase on the level of $500 \mathrm{PU} / \mathrm{kg}$ with $0.35 \%$ (1 to 21 days) and $0.27 \%$ (22 to 42 days) of available phosphorus was similar to the ones that received control feed, with no phytase addition.

Regarded to the performance (feed consumption, weight gain and alimentary conversion), the use of phytase in the feed provided similar results between the evaluated calcium and available phosphorus levels, showing that the relationship calcium:AvP, of $2: 1$ was adequate. Feed with $0.65 \%$ and $0.325 \%$ or $0.55 \%$ and $0.275 \%$ of calcium and available phosphorus, respectively, provide a higher weight gain than the control diet, formulated with nutritional level recommended by Rostagno et al. (2005). The results presented here are in agreement to the previous works (Cowieson \& Adeola, 2005; Liu et al., 2007, 2008), confirming that the use of phytase in the diet enhances the feed consumption, weight gain and food conversion in broilers. Therefore, there is the possibility to reduce inorganic sources for these elements in the feed formulation. These results confirm the collocation by Choct (2006), that the exogen phytase allows the supply of up to $70 \%$ of phytic phosphorus in the feed.

A phytase unit(PU) is defined, according to Engelen et al. (1994) as the enzyme quantity that releases 1 ìmol of inorganic phosphorus per minute, originated in the sodium phytate 0.0015 mol. $\mathrm{L}^{-1}$ at pH 5.5 and temperature of $37^{\circ} \mathrm{C}$. 
Table 3 - Broiler performance in the period between 8 and 35 days of age fed with feed containing phytase and different available phosphorus and calcium levels

\begin{tabular}{|c|c|c|c|c|c|}
\hline \multirow[b]{3}{*}{ Available phosphorus - AvP (\%) } & \multicolumn{5}{|c|}{ Feed intake (g) } \\
\hline & \multicolumn{4}{|c|}{ Calcium (\%) } & \multirow[t]{2}{*}{ Average } \\
\hline & 0.85 & 0.75 & 0.65 & 0.55 & \\
\hline 0.375 & 3172 & 3114 & 3160 & 3192 & 3160 \\
\hline 0.325 & $3222^{*}$ & $3240^{*}$ & $3285^{*}$ & 3130 & 3219 \\
\hline 0.275 & 3067 & 3123 & $3231^{*}$ & $3234^{*}$ & 3164 \\
\hline Average & 3154 & 3159 & 3225 & 3185 & \\
\hline Control & & & & & 3096 \\
\hline \multirow{3}{*}{ Coefficient of variance (\%) } & & & 2.82 & & \\
\hline & \multicolumn{5}{|c|}{ Weight gain (g) } \\
\hline & \multicolumn{4}{|c|}{ Calcium (\%) } & Average \\
\hline AvP (\%) & 0.85 & 0.75 & 0.65 & 0.55 & \\
\hline 0.375 & 1938 & 1928 & 1926 & 1930 & 1931 \\
\hline 0.325 & 1955 & 1956 & $1993^{*}$ & 1959 & 1966 \\
\hline 0.275 & 1926 & 1921 & 1942 & $1977^{*}$ & 1941 \\
\hline Average & 1939 & 1935 & 1954 & 1955 & \\
\hline Control & & & & & 1912 \\
\hline \multirow[t]{3}{*}{ Coefficient of variance (\%) } & & & 2.30 & & \\
\hline & \multicolumn{5}{|c|}{ Feed conversion } \\
\hline & \multicolumn{4}{|c|}{ Calcium (\%) } & Average \\
\hline AvP (\%) & 0.85 & 0.75 & 0.65 & 0.55 & \\
\hline 0.375 & 1.638 & 1.615 & 1.641 & 1.654 & 1.637 \\
\hline 0.325 & 1.648 & 1.656 & 1.648 & 1.599 & 1.638 \\
\hline 0.275 & 1.593 & 1.626 & 1.664 & 1.636 & 1.630 \\
\hline Average & 1.627 & 1.633 & 1.651 & 1.630 & \\
\hline Control & & & & & 1.619 \\
\hline Coefficient of variance (\%) & & & 2.39 & & \\
\hline
\end{tabular}

${ }^{*}$ Differs $(\mathrm{P}<0.05)$ from the control diet by Dunnett test.

It is important to outline that each $0.1 \%$ of available phosphorus released by phytase is equivalent to 4.5 to $5.5 \mathrm{~kg}$ of bicalcic phosphate, depending on the considered nutritional matrix for the ingredients (Lecznieski, 2005) quoted by Caries et al. (2008).

There was significant difference $(\mathrm{P}<0.05)$ in the ash percentage in the tibia among diets containing $0.55 \%$ and $0.275 \%$ of calcium and available phosphorus, respectively, and the one formulated with regular nutritional levels recommended by Rostagno et al. (2005), with no phytase addition (control). Broilers feed with lower levels of calcium and available phosphorus presented tibia with smaller percentage of ash (Table 4). Despite of the relationship Ca :AvP being 2:1, this feed presented insufficient amount of the studied minerals for an adequate bone mineralization when compared to the control feed. Karunajeewa (1976) concluded that, for the growing phase, $0.60 \%$ of calcium and $0.57 \%$ of phosphorus, respectively, are sufficient to the adequate growth and mineralization rates, when the minerals are present in a highly available form.

By analyzing the factorial (Table 4), it was observed that there was no interaction $(\mathrm{P}>0.05)$ among available phosphorus and calcium levels with the bone ashes in the tibia. The reduction of the available phosphorus and calcium levels ( $\mathrm{P}>0.05)$ did not influence the percentage of bone ashes when the feed was supplemented with phytase, thus confirming that phytase improves the availability of calcium and phosphorus for the bone, which are in agreement to the results obtained by Yan et al. (2003), in a study with broilers in the 42-63 days of age phase of age, and by Laurentiz et al. (2007), in a research with broilers from 36 to 42 days of age. In those studies,it is related that reduced available phosphorus levels with the use of phytase in the diets avoided the differences in the bone ash disposal among the supplementation levels.

Although it had been satisfactory the performance of the broilers that received feed with $0.55 \%$ and $0.275 \%$ of calcium and available phosphorus, respectively, the reduction of these levels by supplementation of $500 \mathrm{PU} / \mathrm{kg}$ of feed, is not enough for a good bone mineralization on the tibia. In some ways, these results are contrary to the information given by Choct (2006) and a possible consequence of that is bone malformation and bone fracture at the moment of the collection.

According to the results by Pérsia \& Saylor (2006), the addition of $600 \mathrm{PU}$ of phytase/kg in the feed allows an increase in the bone ashes from $0.44 \%$ to $0.48 \%$ for broilers from 5 to 23 days of age. Fukayama et al. (2008) verified an 
Table 4 - Average percentage of ashes in the tibia of the broilers at 35 days of age, receiving feed with phytase and different available phosphorus levels and calcium

\begin{tabular}{|c|c|c|c|c|c|}
\hline \multirow[b]{3}{*}{ Available phosphorous (\%) } & \multicolumn{5}{|c|}{ Bone ash (\%) } \\
\hline & \multicolumn{4}{|c|}{ Calcium (\%) } & \multirow[t]{2}{*}{ Average } \\
\hline & 0.85 & 0.75 & 0.65 & 0.55 & \\
\hline 0.375 & 50.70 & 51.18 & 50.00 & 49.88 & 50.44 \\
\hline 0.325 & 50.77 & 50.51 & 50.01 & 51.08 & 50.59 \\
\hline 0.275 & 50.62 & 50.58 & 50.83 & $48.78^{*}$ & 50.20 \\
\hline Control & & & & & 51.37 \\
\hline Coefficient of variance (\%) & & & 2.31 & & \\
\hline
\end{tabular}

* Differs $(\mathrm{P}<0.05)$ from the control diet by Dunnett test.

increase in the bone ash in the tibia of broilers from 1 to 20 days of age, deriving from supplementation with 750 PU of phytase/kg. These authors reinforced the results obtained here, in which the use of the phytase enzyme responds satisfactorily when calcium and available phosphorus levels in the diets are reduced. This is because the observed values regarded to the bone ash percentage of the broilers that received lower levels of calcium and available phosphorus in the feed are similar to the ones with higher levels of these elements. However, when it was used $0.55 \%$ and $0.275 \%$ of calcium and available phosphorus, respectively, bone mineralization was worse than in the control diet.

In comparison to the control diet, it was evidenced a higher metabolizable energy value (Table 5) for broilers that received feed with $0.325 \%$ of available phosphorus and $0.75 \%$ or $0.65 \%$ of calcium and a smaller energetic value in the feed with $0.55 \%$ of calcium, independently of the available phosphorus level used, and $0.65 \%$ and $0.275 \%$ of calcium and available phosphorus, respectively, although this smaller energetic value did not influence the performance of the broilers. It is also outlined that, the improvement of the metabolizable energy in the feed with
$0.65 \%$ of calcium and $0.325 \%$ of available phosphorus was approximately $2.4 \%$.

Interaction was observed $(\mathrm{P}<0.05)$ between calcium and available phosphorus levels utilized in the experimental feed. Therefore, by using $0.375 \%$ of available phosphorus in the feed, metabolizable energy was linearly reduced along with calcium level of the diet $($ AMEn $=2855.54$ 415.89X, $\mathrm{R}^{2}=0.79$ ); however, with levels of $0.325 \%$ and $0.275 \%$ of available phosphorus, the squared effect was, with the respectively equations the following (AMEn = $314.10+8266.12 \mathrm{X}-5805.78 \mathrm{X}^{2}, \mathrm{R}^{2}=0.97$; AMEn $=2028.80$ $+2743.97 \mathrm{X}-1727.58 \mathrm{X}^{2}, \mathrm{R}^{2}=0.82$ ), through which it was obtained better energetic levels in the great levels of calcium inclusion of 0.71 and $0.79 \%$, respectively, for feed with $0.325 \%$ and $0.275 \%$ of available phosphorus.

It was obtained higher metabolizable energy $(\mathrm{P}<0.05)$ for calcium level of $0.85 \%$ at $0.375 \%$ of available phosphorus. For feed containing $0.75 \%$ of calcium level, the best results $(\mathrm{P}<0.05)$ were obtained with $0.325 \%$ and $0.275 \%$ of available phosphorus and, in diets with $0.65 \%$ of calcium level, the highest value occurred with $0.325 \%$ of available phosphorus, followed by the levels of $0.375 \%$ and $0.275 \%$ of available phosphorus $(\mathrm{P}<0.05)$. Finally, with $0.55 \%$ of calcium, there

Table 5 - Apparent metabolizable energy by nitrogen balance (AMEn), in feed with phytase and different available phosphorus levels and calcium

\begin{tabular}{|c|c|c|c|c|c|}
\hline \multirow[b]{3}{*}{ Available phosphorous (\%) } & \multicolumn{5}{|c|}{ AMEn (kcal/kg of dry matter) } \\
\hline & \multicolumn{4}{|c|}{ Calcium (\%) } & \multirow[t]{2}{*}{ Average } \\
\hline & 0.85 & 0.75 & 0.65 & 0.55 & \\
\hline $0.375^{1}$ & $3,209 a$ & $3,148 b$ & $3,166 \mathrm{~b}$ & $3,064 *$ & 3,147 \\
\hline $0.325^{2}$ & $3,150 b$ & $3,233 * a$ & $3,248 * a$ & $3,099 *$ & 3,182 \\
\hline $0.275^{2}$ & $3,156 b$ & $3,192 \mathrm{a}$ & $3,109 * c$ & $3,076 *$ & 3,133 \\
\hline Average & 3,172 & 3,191 & 3,174 & 3,080 & \\
\hline Control & & & & & 3,172 \\
\hline Coefficient of variance (\%) & & & 1.34 & & \\
\hline
\end{tabular}

${ }^{*}$ Differs $(\mathrm{P}<0.05)$ from the control diet by Dunnett test.

Means with different letters in the columns differ $(\mathrm{P}<0.05)$ by SNK test.

${ }^{1}$ Linear effect.

2 Squared effect. 
was no difference among the three studied levels of available phosphorus ( $\mathrm{P}>0.05)$ for metabolizable energy.

The results obtained in this work are in agreement to the ones obtained by Namkung \& Lesson (1999) and Ravindran et al. (2001), who, working with birds from 1 to 15 and from 1 to 28 days of age, found improvement of $1.0 \%$ and $2.3 \%$ in the metabolizable energy value, respectively, in the feed with phytase addition, regarded to the one with no enzyme addition. In this work, the feed with $0.325 \%$ of available phosphorus and $0.65 \%$ of calcium showed an improvement of $2.38 \%$ in the metabolizable energy when compared to the control feed, with no enzyme, representing a variance of $76 \mathrm{kcal}$ of metabolizable energy/kg of feed. Juanpere et al. (2004) evaluated levels of 0.45 and $0.27 \%$ of available phosphorus, also with and without phytase, and noted that the AME decreased as the available phosphorus reduced.

The means of the metabolizability coefficient of the dry matter of the experimental diets were similar to the control diets, except for the one with $0.65 \%$ of calcium and $0.325 \%$ of available phosphorus and those with $0.55 \%$ of calcium in all studied available phosphorus levels (Table 6). In part, these findings are in agreement to the ones discovered by Tejedor et al. (2001), who noticed improvement in the metabolizability coefficient of dry matter when $750 \mathrm{PU}$ phytase $/ \mathrm{kg}$ was added in the feed with levels of $0.80 \%$ of calcium and $0.33 \%$ of available phosphorus with broilers from 10 to 24 days of age. However, the results of this work indicate that reducing calcium to approximately $35 \%$ of the recommended level affects the metabolizability coefficient of dry matter, even when supplemented with phytase at
500PU/kg of feed, a similar confirmation to the one observed in the metabolizable energy values.

There was no interaction ( $\mathrm{P}>0.05$ ) between the available phosphorus and calcium in the diets for the metabolizability coefficient of the dry matter, according to the equation $\left(\mathrm{MCDM}=74.99-0.797 \mathrm{X}, \mathrm{R}^{2}=0.79\right)$. Therefore, the decrease of calcium levels of the diets had linear negative effect $(\mathrm{P}<0.05)$ in the metabolizability coefficient of dry matter $(\mathrm{P}<0.05)$. In other hand, higher MCDM $(\mathrm{P}<0.05)$ were observed when the feed contained $0.325 \%$ of available phosphorus, independently of the calcium level used in it.

The worst $(\mathrm{P}<0.05)$ metabolizability coefficient of crude protein was observed in broilers that received feed with the lowest calcium level, independently of the used available phosphorus level, and the feed with $0.85 \%$ and $0.375 \%$ and $0.75 \%$ and $0.325 \%$ of calcium and available phosphorus, respectively, when compared to the metabolizability coefficient of crude protein of the broilers that received regular feed, with no phytase supplementation. On the other hand, when the relationship calcium:AvP is kept in the ratio 2 : 1 , in the feed with $0.65 \%$ of calcium and $0.325 \%$ of available phosphorus, supplemented with phytase, the metabolizability coefficient of crude protein was superior to the control feed, a fact similar to the observed for metabolizable energy and weight gain of the broilers, although the weight gain of the broilers receiving $0.55 \%$ and $0.275 \%$ of calcium and available phosphorus did not differ from the control.

There was an interaction $(\mathrm{P}<0.05)$ among calcium and available phosphorus levels in the experimental feed. A

Table 6 - Metabolizability coefficients of dry matter and crude proteinin broilers fed with feed supplemented with phytase and different available phosphorus levels and calcium

\begin{tabular}{|c|c|c|c|c|c|}
\hline \multirow[b]{3}{*}{ Available phosphorous (\%) } & \multicolumn{5}{|c|}{ Metabolizability coefficient of dry matter (\%) } \\
\hline & \multicolumn{4}{|c|}{ Calcium (\%) } & \multirow[t]{2}{*}{ Average } \\
\hline & 0.85 & 0.75 & 0.65 & 0.55 & \\
\hline 0.375 & 73.92 & 72.61 & $72.07 *$ & $71,56 *$ & $72.54 b$ \\
\hline 0.325 & 74.05 & 74.59 & 74.26 & $71,83 *$ & $73.68 a$ \\
\hline 0.275 & 74.20 & 75.07 & 72.23 & $70,34 *$ & $72.96 b$ \\
\hline Control & & & & & 74.02 \\
\hline \multirow[t]{2}{*}{ Coefficient of variance (\%) } & \multicolumn{4}{|c|}{2.14} & \\
\hline & \multicolumn{4}{|c|}{$\begin{array}{c}\text { Metabolizability coefficient of crude protein (\%) } \\
\text { Calcium (\%) }\end{array}$} & Average \\
\hline Available phosphorous (\%) & 0.85 & 0.75 & 0.65 & 0.55 & \\
\hline $0.375^{2}$ & $57.37 * \mathrm{~b}$ & $61.30 \mathrm{a}$ & $62.10 \mathrm{ab}$ & $57.51 *$ & 59.57 \\
\hline $0.325^{3}$ & $60.58 \mathrm{a}$ & $58.21 * b$ & $64.57 * \mathrm{a}$ & $57.77 *$ & 60.28 \\
\hline Average & 60.25 & 60.60 & 62.46 & 57.22 & \\
\hline Control & & & & & 61.58 \\
\hline Coefficient of variance (\%) & & & 3.54 & & \\
\hline
\end{tabular}


cubic effect was noted when $0.325 \%$ of available phosphorus in the feed was used, $(\mathrm{MCCP}=-1192.51+5447.38 \mathrm{X}-$ $\left.7775.26 X^{2}+3649.82 X^{3}, R^{2}=1.0\right)$ and a squared effect when the available phosphorus was raised up to $0.375 \%$ or reduced to $0.275 \%$ in the feed, with the respective equations $\left(\mathrm{MCCP}=41.41+297.35 \mathrm{X}-213,26 \mathrm{X}^{2}, \mathrm{R}^{2}=0.99\right.$ e $\mathrm{MCCP}=$ $\left.0.330+154.70 \mathrm{X}-95.66 \mathrm{X}^{2}, \mathrm{R}^{2}=0.99\right)$ as the best metabolizability coefficient of crude protein were obtained by including great levels of $0.70 \%$ and $0.81 \%$ of calcium for the feed with $0.375 \%$ and $0.275 \%$ of available phosphorus, respectively.

The results agree with the ones reported by Santos et al. (2008), who found an increase of $2.1 \%$ in the metabolizability coefficient of crude protein on broilers at 35 days of age, receiving feed with $500 \mathrm{PU} / \mathrm{kg}$ of phytase. This confirms that the phytase not only releases minerals attached in the phytate molecule, but also proteins and amino acids to be absorbed.

The effect of the microbial phytase over the protein digestibility and mineral availability must be quantified in order to reduce the costs with feeding. The protein digestibility and the phytic acid of the food are two factors that determine the magnitude of this effect(Tejedor et al., 2001).

According to Oliveira et al. (2008), the phytase inclusion in the diets was sufficient to increase the crude protein in $7.46 \%$ of these diets and the metabolizability of crude protein improved in $2 \%$ with the phytase inclusion, regardless to available phosphorus levels. In this work, the phytase supplementation, in $500 \mathrm{PU} / \mathrm{kg}$, in the feed with $0.65 \%$ of calcium and $0.325 \%$ of available phosphorus, made it possible to enhance the metabolizability coefficient of crude protein up to $4.85 \%$.

The results observed in this experiment are similar to the ones reported by Lan et al. (2002) and Wu et al. (2004), who evaluated diets with low available phosphorus levels in $0.34 \%$ and $0.30 \%$, respectively, and discovered better digestibility coefficients of crude protein and dry matter attributed to supplementation of the diets with phytase.

Therefore, although there were differences observed in each of the evaluated parameter in the metabolism experiment, there was no influence among the evaluated parameters in the performance experiment. This shows that, even with the calcium and available phosphorus levels being lowered to the lowest point, broilers at 8 to 35 days of age present a satisfactory development when received 500 PU phytase/kg of feed. The best results of metabolizable energy, metabolizability of dry matter and crude protein were obtained in feed with the relationship calcium:AvP of $2: 1$ ( $0.65 \%$ of calcium and $0.325 \%$ of available phosphors) showing that, by using supplementary phytase, it is possible to reduce calcium and available phosphorus levels, as long as the relationship 2:1 is maintained, without affecting the performance.

The utilization of $500 \mathrm{PU}$ of phytase/kg of feed was not enough to supply $70 \%$ of phytic phosphorus as reported by Choct (2006). However, these results prove that the addition of $500 \mathrm{PU}$ phytase/kg of feed allows a reduction of $0.10 \%$ of the available phosphorus level and $0.20 \%$ of diet calcium in the feed without changes on the development of the broilers, as observed in the feed with $0.65 \%$ and $0.325 \%$ of calcium and available phosphorus, respectively, maintaining the relation of calcium:AvP in 2:1.

\section{Conclusions}

The reduction of calcium and available phosphorus levels of the feed to $0.55 \%$ and $0.275 \%$ respectively, does not interfere on the performance of the broilers, but it compromises the bone ash percentage. The calcium level of $0.65 \%$ and available phosphorus level of $0.325 \%$ with supplementation of $500 \mathrm{ftu}$ phytase/kg in feed for broilers in the phase from 8 to 35 days of age are adequate to the performance and the bone mineralization by improving the digestibility of dry matter, protein and energy.

\section{References}

ASSOCIATION OF OFFICIAL ANALYTICAL CHEMIST AOAC. Official methods of analysis: agricultural chemicals, contaminants and drugs. 15.ed. Washington, DC, 1990. 1230p.

BORGES, F.M.O.; VELOSO, J.A.F.; BAIÃO, N.C. et al. Avaliação de fontes de fósforo para frangos de corte em crescimento, considerando-se o fósforo disponível. Arquivos Brasileiros de Medicina Veterinária e Zootecnia, v.49, n.5, p.629-638, 1997.

CAIRES, C.M.; FAGUNDES, N.S.; FERNANDES, E.A. et al. Enzimas na alimentação de frangos de corte. Revista Eletrônica Nutritime, v.5, n.1, p.491-497, 2008.

CHOCT, M. Enzymes for the feed industry: past, present and future. Word's Poultry Science Journal, v.62, n.1, p.5-15, 2006.

COWIESON, A.J.; ADEOLA, O. Carbohydrases, protease, and phytase have an additive beneficial effect in nutritionally marginal diets for broiler chicks. Poultry Science, v.84, p.1869-1867, 2005.

ENGELEN, A.J.; van der HEEFT, F.C.; RANDSDORP, P.H.G. et al. Simple and rapid determination of phytase activity. Journal of AOAC International, v.77, n.3, p.760-764, 1994.

FUKAYAMA, E.H.; SAKOMURA, N.K.; DOURADO, L.R.B. et al. Efeito da suplementação de fitase sobre o desempenho e a digestibilidade dos nutrientes em frangos de corte. Revista Brasileira de Zootecnia, v.37, n.4, p.629-635, 2008.

JUANPERE, J.; PÉREZ-VENDRELL, A.M.; BRUFAU, J. Effect of microbial phytase on broilers fed barley-based diets in the presence or not of endogenous phytase. Animal Feed Science Technology, v.115, p.265-279, 2004.

KARUNAJEEWA, H. Effect of some feed additives on the performance of broiler chicks fed diets containing high levels 
of meat and bone meal. Australian Journal of Experimental Agriculture and Animal Husbandry, v.16, p.685-690, 1976.

LAN, G.Q.; ABDULLAH, N.; JALALUDIN, S. et al. Efficacy of supplementation of a phytase-producing bacterial culture on the performance and nutrient use of broiler chickens fed corn-soybean meal diets. Poultry Science, v.81, p.1522-1533, 2002.

LAURENTIZ, A.C.; JUNQUEIRA, O.M.; FILARDI, R.S. et al. Efeito da adição da enzima fitase em rações para frangos de corte com redução dos níveis de fósforo nas diferentes fases de criação. Ciência Animal Brasileira, v.8, n.2, p.207-216, 2007.

LESKE, K.L.; COON, C.N. A bioassay to determine the effect of phytase on phytate phosphorus hydrolysis and total phosphorus retention of feed ingredients as determined with broilers and laying hens. Poultry Science, v.78, n.8, p.1151-1157, 1999.

LIU, N.; LIU, G.H.; LI, F.D. et al. Efficacy of phytases on egg production and nutrient digestibility in layers fed reduced phosphorus diets. Poultry Science, v.86, p.2337-2342, 2007.

LIU, N.; RU, Y.J.; COWIESON, A.J. et al. Effects of phytate and phytase on the performance and immune function of broilers fed nutritionally marginal diets. Poultry Science, v.87, p.1105-1111, 2008.

MAGA, J.A. Phytate: its chemistry, occurrence, food interactions, nutritional significance, and methods of analysis. Journal of Agricultural and Food Chemistry, v.30, p.1-9, 1982.

MATTERSON, L.D.; POTTER, L.M.; STUTZ, M.W. et al. The metabolizable energy of feed ingredients for chickens. Storrs: The University of Connecticut-Agricultural Experiment Station, 1965. 11p. (Research Report, 7).

NAMKUNG, H.; LEESON, S. Effect of phytase enzyme on dietary Nitrogen-corrected apparent metabolizable energy and ileal digestibility of nitrogen and amino acids in broiler chicks. Poultry Science, v.78, p.1317-1319, 1999.

OLIVEIRA, M.C.; GRAVENA, R.A.; MARQUES, R.H. et al. Utilização de nutrientes em frangos alimentados com dietas suplementadas com fitase e níveis reduzidos de fósforo nãofítico. Arquivo Brasileiro de Medicina Veterinária e Zootecnia, v.60, n.2, p.436-441, 2008.

PERSIA, M.E.; SAYLOR, W.W. Effects of broiler strain, dietary nonphytate phosphorus, and phytase supplementation on chick performance and tibia ash. Journal Applied Poultry Research, v.15, p.72-81, 2006.

QIAN, H.; KORNEGAY, E.T.; DENBOW, D.M. Utilization of phytate phosphorus and calcium as influenced by microbial phytase, cholecalciferol, and the calcium: total phosphorus ratio in broiler diets. Poultry Science, v.76, n.5, p.37-46, 1997.

RAVINDRAN, V.; SELLE, P.H.; RAVINDRAN, G. et al. Microbial phytase improves performance, apparent metabolizable energy, and ileal amino acid digestibility of broilers fed a lysine-deficient diet. Poultry Science, v.80, p.338-344, 2001.

RODRIGUES, P.B.; MARTINEZ, R.S.; FREITAS, R.T.F. et al. Influência do tempo de coleta e metodologias sobre a digestibilidade e o valor energético de rações para aves. Revista Brasileira de Zootecnia, v.34, n.3, p.882-889, 2005.

ROSTAGNO, H.S.; ALBINO, L.F.T.; DONZELE, J.L. et al. Tabelas brasileiras para aves e suínos: composição de alimentos e exigências nutricionais. 2.ed. Viçosa, MG: UFV, 2005. 186p.

SANTOS, R.; ZANELLA, I.; BONATO, E.L. et al. Diminuição dos níveis de cálcio e fósforo em dietas com farelo de arroz integral e enzimas sobre o desempenho de frangos de corte Ciência Rural, v.34, n.2, p.517-521, 2004.

SANTOS, F.R.; HRUBY, M.; PIERSON, E.E.M. et al. Effect of phytase supplementation in diets on nutrient digestibility and performance in broiler chicks. Journal Applied Poultry Research, v.17, p.191-201, 2008. doi:10.3382/japr.200700028.

SCHOUlTEN, N.A.; TEIXEIRA, A.S.; SILVA, H.O. et al. Efeitos dos níveis de cálcio da ração suplementada com fitase sobre a absorção de minerais em frangos de corte de 22 a 42 dias. Ciência Animal Brasileira, v.3, n.1, p.31-37, 2002.

SEBASTIAN, S.; TOUCHBURN, S.P.; CHAVEZ, E.R. The effects of supplemental microbial phytase on the performance and utilization of dietary calcium, phosphorus, copper, and zinc in broiler chickens fed corn-soybeans diets. Poultry Science, v.75, n.6, p.729-736, 1996.

SEGUEILHA, L.; LAMBRECHTS, C.; BOZE, H. et al. Purification and properties of the phytase from Schwanniomyces castellii. Journal of Fermentation and Bioengineering, v.74, p.7-11, 1992.

SILVA, Y.L.; RODRIGUES, P.B.; FREITAS, R.T.F. et al. Redução de proteína e fósforo em rações com fitase para frangos de corte, no período de 1 a 21 dias de idade: desempenho e teores de minerais na cama. Revista Brasileira de Zootecnia, v.35, n.3, p.840-848, 2006.

TEJEDOR, A.A.; ALBINO, L.F.T.; ROSTAGNO, H.S. et al. Efeito da adição da enzima fitase sobre o desempenho e a digestibilidade ileal de nutrientes. Revista Brasileira de Zootecnia, v.30, n.3, p.802-808, 2001.

UNIVERSIDADE FEDERAL DE VIÇOSA - UFV. Manual de utilização do programa SAEG - Sistema para Análises Estatísticas e Genéticas. Viçosa, MG, 1992. 59p.

VIVEROS, A.; BRENES, A.; ARIJA, I. Effects of microbial phytate supplementation on mineral utilization and serum enzyme activities in broiler chicks fed different level of phosphorus. Poultry Science, v.81, p.1172-1183, 2002.

WU, Y.B.; RAVINDRAN, V.; HENDRIKS, W.H. Evaluation of a microbial phytase, produced by solid state fermentation, in broiler diets: II. Influence on phytate hydrolysis, apparent metabolizable energy, and nutrient utilization. Journal Applied Poultry Research, v.13, p.561-569, 2004.

YAN, F.; KERSEY, J.H.; FRITTS, C.A; WAL-DROUP, P.W. Phosphorus requirements of broiler chicks six to nine weeks of age as influenced by phytase supplementation. Poultry Science, v.82, p.94-300, 2003. 